\title{
Specialisten in verwachting van opleidingsherziening
}

In 2003 konden we op het NVMO-congres nog vaststellen dat medisch onderwijskundigen maar weinig toegang hadden tot de medische specialistenopleidingen. Anno 2005 lijkt deze situatie flink veranderd. In ieder geval wordt de behoefte aan onderwijskundige hulp bij het herzien van de curricula voor de opleidingen van medisch specialisten duidelijk ervaren. De commissie LeGrand heeft voor de Nederlandse overheid aanbevelingen geformuleerd voor de zorgopleidingen ${ }^{1}$ die door de stuurgroep Modernisering van de Opleidingen voor de Beroepen in de Gezondheidszorg (MOBG) in samenspraak met 'het veld' moeten worden verwezenlijkt. Het Centraal College Medische Specialismen (CCMS) was al langer bezig te werken aan een visie over hoe de medisch specialist van de toekomst opgeleid dient te worden, en kon snel inspelen op de overheidswens tot modernisering.

Er zijn enkele opvallende doelstellingen bij de beleidsmakers herkenbaar. De overheid heeft als hoofddoel het opvangen van een dreigend artsen- en specialistentekort door de vorming van nieuwe zorgprofessionals zoals de nurse practitioner, de physician assistent en de basisspecialist, en verder door verkorting van het opleidingscontinuüm van student geneeskunde tot medisch specialist. Het CCMS vervult in de hoofddoelen de wens van de maatschappij om een medisch specialist niet alleen op te leiden als medisch expert en wetenschapper, zoals dat de traditie was, maar ook voor de algemene competenties 'communicatie', 'samenwerking', 'organi- satie', 'maatschappelijk handelen' en 'professionaliteit'. Daarvoor zijn de in Canada ontwikkelde CanMEDS $2000^{2}$ herschreven tot een soort NedMEDS die beter dan de CanMEDS aansluiten op het raamplan voor de Nederlandse geneeskundeopleiding. Verder stuurt het CCMS sterk aan op de invoering van een verbeterde didactische benadering in de klinische opleidingen. Er is onderwijskundig advies ingewonnen en er zijn duidelijke (en bindende) aanbevelingen gedaan, zoals het opleiden in modulen, het gebruik van cursorisch onderwijs, het doen van observaties van de arts in opleiding tot specialist (aios) in gestructureerde 'korte klinische beoordelingen' en het laten bijhouden van een portfolio met reflectie op de ontwikkeling in de diverse competenties. Verder werd docentprofessionalisering tot norm verheven.

Het moge duidelijk zijn dat de opleidingsherziening van de medisch specialistische curricula een belangrijke kwaliteitswinst moet geven voor het medisch onderwijs in ons land. Medici en onderwijskundigen moeten deze herziening in samenspraak gestalte geven. Waar staan wij nu en waar vinden we weerstanden?

\section{Curriculumbouw}

Op dit moment is het merendeel van de verschillende specialismen actief in het beschrijven van curricula op basis van de voorschriften van het CCMS en de wens om een kwalitatief hoogwaardige opleiding tot medisch specialist te kunnen garanderen. De Nederlandse Vereniging 
voor Obstetrie en Gynaecologie heeft de bevalling van het curriculum 'NVOGHOOG' (Herziening Opleiding Obstetrie en Gynaecologie) achter de rug en er zijn meer wetenschappelijke verenigingen waar de weeën al opspelen. Bij de curriculumbouw is het ingewikkeld om de tot NedMEDS omgebouwde CanMEDS 2000 te voorzien van een levensvatbaar opleidingsplan. In dit nummer van TMO laten Verkerk, De Bree en Jaspers een goed voorbeeld zien van het denkwerk dat over de invulling van de algemene competenties plaatsvindt. In hun artikel wordt de algemene competentie 'professionaliteit' belicht als contextgebonden. Maar ook de ogenschijnlijk eenvoudiger algemene competenties van samenwerking en organisatie geven de curriculumbouwers veel hoofdbrekens. Hoe geef je binnen het opleidingscontinuüm een invulling aan deze algemene competenties die het niveau van 'de open deur' overstijgt? In discussies hierover zijn twee richtingen waarneembaar.

De ene richting wijst op het disciplineoverstijgende karakter van de competenties. Dat wordt in de uitvoerende sfeer vervolgens vertaald naar de heel praktische insteek van het multidisciplinair verzorgen van cursorisch onderwijs. Dat algemene competenties als samenwerking en organisatie in hun concepten grotendeels disciplineoverstijgend zijn, lijkt duidelijk. Maar of het doceren ervan het beste disciplineoverstijgend en buiten de klinische context op een cursus zou kunnen plaatsvinden, is minder duidelijk.

Een andere richting die ter sprake komt is dat iedere discipline contextgebonden voorbeelden van samenwerking en organisatie zou moeten benoemen om het denken in deze algemene competenties te verduidelijken voor de klinisch docenten en de aios. De contextgebonden voorbeel- den zijn dan bruikbaar voor onderwijs en toetsing op de werkvloer en vormen een praktische vertaling van de onderliggende (disciplineoverstijgende) samenwerkingsen organisatieconcepten. Welke denkrichting men ook volgt, er zullen keuzes gemaakt moeten worden welke concepten de nadruk gaan krijgen in respectievelijk de opleiding tot basisarts en de opleiding tot medisch specialist. Over die vraag is moeilijk literatuur te vinden, laat staan passend wetenschappelijk onderzoek dat gebruikt kan worden voor het maken van gefundeerde keuzes.

Een competentiegericht curriculum voor de specialistenopleiding vraagt om een persoonlijk ontwikkelplan voor de aios op basis van bewijsvoering van opgebouwde competenties vanuit een portfolio. Individuele startniveau's verschillen sterk bij aios, en de ene aios heeft een steilere leercurve dan de andere. Hoe vertaal je dat naar de klinische werkvloer waar het leren plaatsvindt? Hoe wordt een modulair opgebouwd curriculum voldoende flexibel ingericht, zodat effectief portfolioleren zich kan vertalen in een individueel opleidingstraject? Zo lopen curriculumbouwers momenteel tegen vele aansprekende vragen op waar enthousiaste medisch onderwijskundigen goed mee aan de slag kunnen. Medisch specialisten die de opleidingen vorm geven, kunnen niet meer zonder onderwijskundig advies, en de onderwijskundige krijgt de kans om de klinische opleidingen te doorgronden en mogelijk zelfs als onderzoeksmateriaal te gebruiken.

\section{Implementatie}

Waar de problemen van de curriculumbouw voldoende zijn opgelost en de plannen een mooie glans vertonen, komt de invoering in de klinische praktijk. Er is vrij veel ervaring met de invoering van nieuwe 
curricula en veranderingen in de opleiding tot basisarts. ${ }^{3}$ Het veranderen van de vervolgopleidingen is een ander verhaal. Enerzijds bestaat er veel idealisme en vinden klinisch docenten het belangrijk om aios goed te begeleiden en te investeren in de opleidingen; anderzijds bestaat er een gevoel van overbelasting en twijfel over de prioriteit van de opleidingsherziening. Men moet niet uit het oog verliezen dat het nog geen tien jaren geleden is dat de 48-urige werkweek werd ingevoerd. Veel leden van opleidingsteams hebben deze opgelegde verandering van stijl, die er in veel gevallen toe leidt dat de aios in een ander arbeidsethos wordt opgeleid dan op de toekomstige werkplek gangbaar is, nog steeds maar nauwelijks verwerkt. Nu komen er nieuwe curricula die de aios meer in de rol van leerling plaatsen en minder in de rol van leverancier van patiëntenzorg. De aios heeft door de nieuwe curricula tijd nodig voor reflectie en cursorisch onderwijs. De aios stelt eisen aan de inhoud van het werk, wanneer na bespreking van het portfolio duidelijk is welke competenties prioriteit verdienen voor verdere ontwikkeling. De aios wil geobserveerd worden en verlangt van het opleidingsteam bruikbare feedback. De opleiding van een aios gaat het opleiderteam duidelijk meer tijd kosten dan in de huidige opleidingscultuur. Waar ooit de aios smeerolie was voor de organisatie, gaat diens rol nu meer lijken op zand in de wielen.

Ondanks deze problemen, die naar verwachting de nodige emoties opleveren, zijn specialisten uit opleidingsteams wel te motiveren om de gevraagde inspanningen te leveren. Ze moeten enthousiast gemaakt worden voor betere didactiek door goede docentprofessionalisering. Ze moeten overtuigd worden van de waarde van de diverse onderdelen van de opleidingsherzieningen door wetenschappelijke bewijsvoering, en de overheid moet de extra inspanningen tastbaar waarderen. Voor medisch onderwijskundigen en onderzoekers op het terrein van het klinisch onderwijs komen er drukke tijden aan. Hopelijk beseft ook de overheid welke kansen er liggen en komt zij met passende ondersteuning bij de bouw van de nieuwe curricula in de specialistenopleidingen. Ook nadat de diverse wetenschappelijke verenigingen van het curriculum zijn bevallen, is deze steun noodzakelijk om het werkelijk van levenskansen te voorzien. In een goede sfeer van geven en nemen van overheid en wetenschappelijke verenigingen die verantwoordelijk zijn voor de medische specialistenopleidingen, krijgen ook medisch onderwijskundigen betere kansen. Momenteel gebeurt veel advieswerk nog onbezoldigd of wordt er bespaard op onderwijskundig advies. De medische specialistenopleidingen verdienen professionele ondersteuning van medisch onderwijskundigen en de herzieningen van curricula dienen vergezeld te gaan van wetenschappelijke evaluaties door medisch onderwijskundigen. Hopelijk kunnen de lezers van TMO hierover nog vele artikelen tegemoet zien!

\section{Fedde Scheele}

\section{Literatuur}

1. LeGrand-van den Bogaard MJM, Rooijen APN van, editors. De zorg van morgen - flexibiliteit en samenhang. Rapport van de Commissie Implementatie Opleidingscontinuüm en Taakherschikking. Den Haag: Ministerie van VWS; juli 2003. Kamerstuk IBE-2401905B. Beschikbaar op: http://www.minvws.nl.

2. Franks J, Jabour M, Tugwell P, et al. Skills for the new millenium: report of the Societal Needs Working Group. Beschikbaar op: http://rcpsc.medical. org/english/publications/canmed_e.html.

3. Gale R, Grant J. AMEE Guide No.10: Managing change in a medical context: guidelines for action. Med Teach 1997;19:239-49. 